\title{
Identifikasi Akuifer Dangkal dan Akuifer Dalam dengan Metode Geolistrik (Kasus: Di Kecamatan Masaran)
}

\author{
Darsono \\ Lab. Geofisika, Jurusan Fisika, FMIPA, Universitas Sebelas Maret, \\ darsono.uns.fisika@gmail.com
}

Received 12-01-2016, Revised 09-02-2016, Accepted 16-03-2016, Published 20-04-2016

\begin{abstract}
Identification of aquifer layer location has been done using Schlumberger configuration of geoelectric resistivity methods in Masaran District. Data collection was performed using resistivity meter OYO Mc-el-ohm series 2119 c having a length of current electrode (AB / 2) from $1.5 \mathrm{~m}$ to 350 meters. Data processing was done using software IP2win. The purpose of this study was to identify the location of confined aquifer and unconfined aquifer. The result showed that litology of aquifer layers were detected as clayed sand, sands and gravel sands. The depth of confined aquifer was detected for TS1 (4.52 meters to 8.57 meters and 22.4 meters to 34 meters), TS2 (8.84 meters to 20.9 meters), TS3 (2.87 meters to 10 meters and 13.3 meters to 41.5 meters), TS4 (20.09 meters to 6.71 meters and 17.3 meters to 36.4 meters) and TS5 (6.3 meters to 25 meters). The thickest layer of confined aquifer was TS3. While, the depth of unconfined aquifer was detected for TS1 (68.1 meters to 78 meters and 94.3 meters to 115 meters), TS2 (36.9 meters to 93.4 meters and 103 meters to 134 meters), TS3 (72.8 meters to 101 meters), TS4 (46.3 meters to 67.5 meters and 82.1 meters to 98 meters), and TS5 (50.1 meters to 93.5 meters and 99.7 meters to 111 meters). The layer thickness of unconfined aquifer were detected for TS1 (30.6 meters), TS2 (86.7 meters), TS3 (28.4 meters), TS4 (37 meters), and TS5 (55 meters). The layer thickness of unconfined aquifer that has the thickest was TS2.
\end{abstract}

Keywords: confined aquifer, unconfined aquifer, Schlumberger, resistivity

\section{ABSTRAK}

Identifikasi lapisan akuifer telah dilakukan dengan menggunakan metode geolistrik resistivitas konfigurasi Schlumberger di Kecamatan Masaran. Pengambilan data dilakukan dengan bentangan $\mathrm{AB} / 2$ dari 1,5 m sampai $350 \mathrm{~m}$ dengan alat resistivitymeter OYO Mc-ohm-el seri 2119c. Pengolahan data menggunakan software IP2win. Tujuan dari penelitian ini adalah untuk mengidentifikasi letak lapisan akuifer dangkal dan akuifer dalam. Hasilnya dapat disimpulkan bahwa litologi akuifer yang terdeteksi berupa pasir lempungan, pasir, dan pasir kerikilan. Lapisan akuifer dangkal terdeteksi pada kedalaman untuk TS1 (4,52 m-8,57 m dan 22,4 m-34 $\mathrm{m})$, TS2 $(8,84 \mathrm{~m}-20,9 \mathrm{~m})$, TS3 $(2,87 \mathrm{~m}-10 \mathrm{~m}$ dan $13,3 \mathrm{~m}-41,5 \mathrm{~m})$, TS4 $(2,09 \mathrm{~m}-6,71 \mathrm{~m}$ dan17,3 m-36,4 m) dan TS5 $(6,3 \mathrm{~m}-25 \mathrm{~m})$. Ketebalan lapisan akuifer dangkal untuk TS1 $(15,82 \mathrm{~m})$, TS2 $(12,11 \mathrm{~m})$, TS3 (35,3 m), TS4 (23,1 m) dan TS5 (22,48 m). Lapisan akuifer dangkal yang mempunyai lapisan paling tebal adalah pada TS3. Lapisan akuifer dalam terdeteksi pada kedalaman untuk TS1 (68,1-78 m dan 94,3-115 m), TS2 (36,9-93,4 m dan 103$134 \mathrm{~m}$ ), TS3 (72,8-101 m), TS4 (46,3-67,5 m dan 82,1-98 m), dan TS5 (50,1-93,5 m dan 99,7$111 \mathrm{~m})$. ketebalan lapisan akuifer dalam terdeteksi untuk TS1 $(30,6 \mathrm{~m})$, TS2 (86,7 m), TS3 (28,4 m), TS4 (37 m), dan TS5 (55 m). Lapisan Akuifer Dalam yang mempunyai lapisan yang paling tebal adalah TS2. 


\section{PENDAHULUAN}

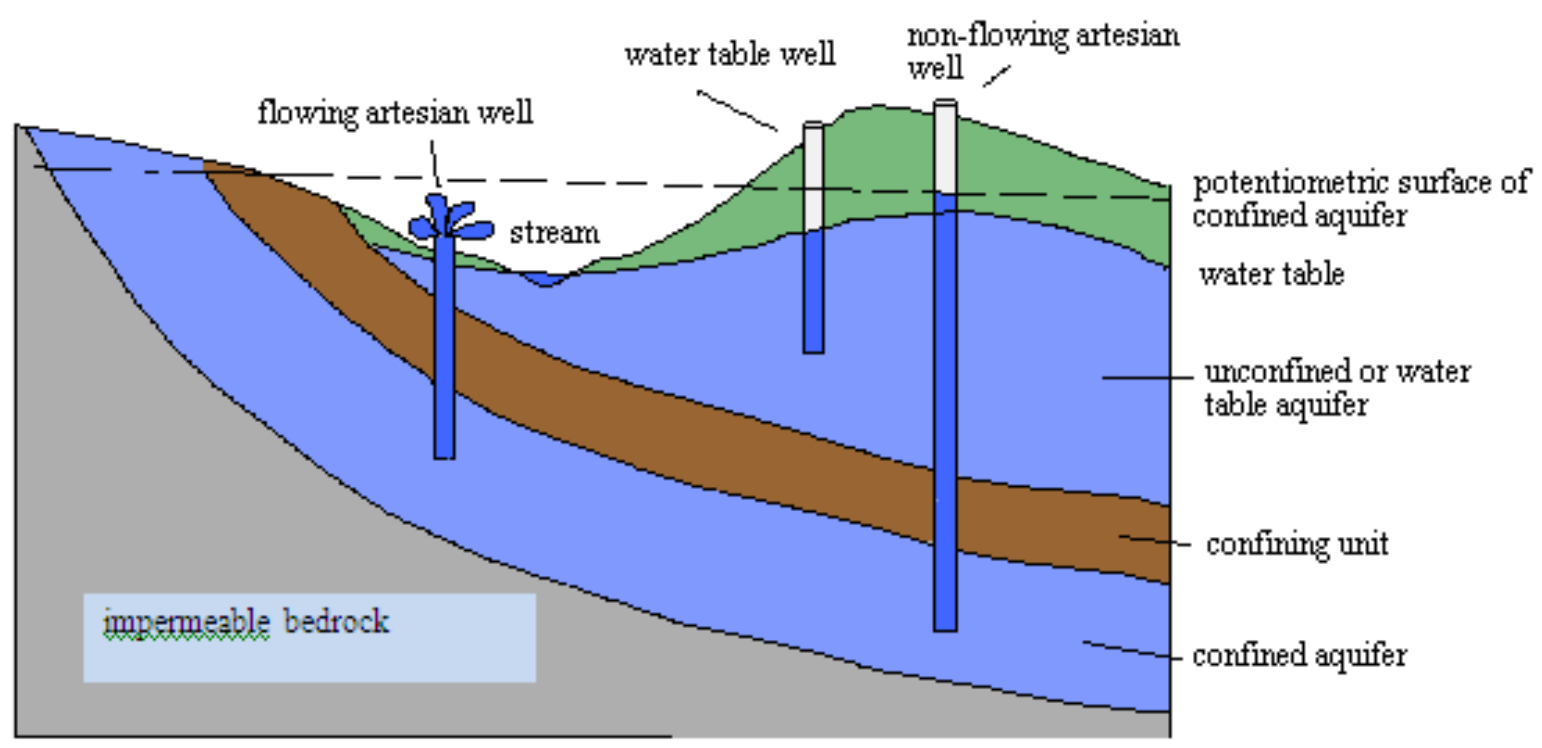

Gambar 1. (Colour online) Sistem Akuifer ${ }^{[4]}$

Air sangat penting bagi setiap makhluk hidup, dapat dikatakan bahwa tidak ada air berarti tidak ada kehidupan. Sumber air dapat berasal dari air hujan, sungai, danau atau air yang tersimpan dalam tanah/akuifer Air yang berada di dalam tanah disebut air tanah. air tanah adalah air yang bergerak di dalam tanah yang terdapat di dalam ruang antar butir-butir tanah yang meresap ke dalam tanah dan bergabung membentuk lapisan tanah disebut akuifer. Lapisan yang mudah dilalui oleh air tanah disebut lapisan permeable, seperti lapisan yang terdapat pada pasir atau kerikil, sedangkan lapisan yang sulit dilalui air tanah disebut lapisan impermeable, seperti lapisan lempung. Akuifer adalah lapisan batuan di bawah permukaan tanah yang mengandung air dan dapat dilalui air. Akuifer adalah formasi geologi atau grup formasi yang mengandung air dan secara signifikan mampu mengalirkan air melalui kondisi alaminya. akuifer merupakan lapisan pembawa air ${ }^{[1]}$. Ditinjau dari muka air tanah, akuifer dikelompokkan menjadi akuifer bebas dan akuifer tertekan ${ }^{[2]}$. Air tanah yang berasal dari akuifer bebas umumnya ditemukan pada kedalaman yang relatif dangkal, kurang dari 40 meter. Selain kedua jenis akuifer tersebut, ada pula yang disebut akuifer semi tertekan dan akuifer semi tidak tertekan yang merupakan kombinasi dari kedua jenis akuifer tersebut ${ }^{[3]}$. Akuifer semi tertekan sering dijumpai di daerah lembah aluvial dan dataran, yang air tanahnya terletak di bawah lapisan yang setengah kedap. Sistem akuifer seperti Gambar 1.

Suatu akuifer mempunyai dua fungsi penting, yaitu sebagai penyimpan seperti sebuah waduk dan sebagai penyalur air seperti jaringan pipa. Kedua fungsi itu diemban oleh poripori atau rongga di dalam batuan akuifer itu. Dua sifat yang berhubungan dengan fungsinya sebagai penyimpan adalah porositas (porosity) dan permeabilitas.

Untuk dapat mendeteksi keberadaan sumber air, yang dideteksi adalah keberadaan lapisan akuifer di daerah tersebut. Lapisan akuifer di dalam tanah tidak dapat terlihat secara langsung dari permukaan, keberadaan akuifer untuk tempat yang berbeda juga kondisinya juga berbeda ( kedalaman dan ketebalan), kadang di suatu tempat sulit ditemukan lapisan akuifer dan ada juga mudah sekali menemukan akuifer. Atau dengan kata lain tidak bisa sembarang langsung melakukan pengeboran, hal ini untuk meminimalisasi biaya pengeboran karena bisa jadi pengeboran yang yang dilakukan kosong tidak ditemukan 
lapisan akuifer. Desa Pringanom dan Desa Krikilan Kecamatan Masaran merupakan daerah yang mengalami kesulitan dalam mencari sumber akuifer. Untuk itu perlu dilakukan survey pendahuluan untuk mengidentifikasi lapisan akuifer yang ada dengan menggunakan metode geolistrik resistivitas, sebelum akan dilakukan pengeboran.

Metode geolistrik resistivitas merupakan metode geolistrik yang mempelajari sifat resistivitas (tahanan jenis) listrik dari lapisan batuan di dalam bumi ${ }^{[5]}$. Pada metode ini dikenal banyak konfigurasi elektroda, diantaranya yang sering digunakan adalah: konfigurasi Wenner, konfigurasi Schlumberger, konfigurasi Wenner-Schlumberger, konfigurasi Dipol-dipol, Rectangle Line Source dan sistem gradien 3 titik ${ }^{[5]}$.

Prinsip kerja dari metode geofisika resistivitas adalah arus listrik diinjeksikan ke dalam bumi melalui dua elektroda arus. Beda potensial yang terjadi diukur melalui dua elektroda potensial. Dari hasil pengukuran arus dan beda potensial untuk setiap jarak elektroda tertentu, dapat ditentukan variasi harga hambatan jenis masing-masing lapisan di bawah titik ukur (titik sounding). Untuk jelasnya penjabaran rumus pada ${ }^{[6]}$

$$
\rho_{a}=K \frac{\Delta \vec{V}}{\vec{I}}
$$

$\rho_{a}=$ hambatan jenis semu, $K=$ faktor geometeri, $\Delta \vec{V}=$ beda potensial, $I=$ arus yang diinjeksikan.

Faktor geometri susunan ini adalah

$$
\begin{aligned}
K s c & =\frac{2 \pi}{\left(\frac{1}{C_{1} P_{1}}-\frac{1}{C_{2} P_{1}}\right)-\left(\frac{1}{C_{1} P_{2}}-\frac{1}{C_{2} P_{2}}\right)} \\
& =\frac{2 \pi}{\left(\frac{1}{a-b}-\frac{1}{a+b}\right)-\left(\frac{1}{a+b}-\frac{1}{a-b}\right)}=\pi\left(\frac{a^{2}-b^{2}}{2 b}\right)
\end{aligned}
$$

$\mathrm{C}_{1}$ dan $\mathrm{C}_{2}$ merupakan tempat elektroda arus. $\mathrm{P}_{1}$ dan $\mathrm{P}_{2}$ merupakan tempat elektroda potensial. Sedangkan TS/TM merupakan tempat titik ukur sounding/mapping.

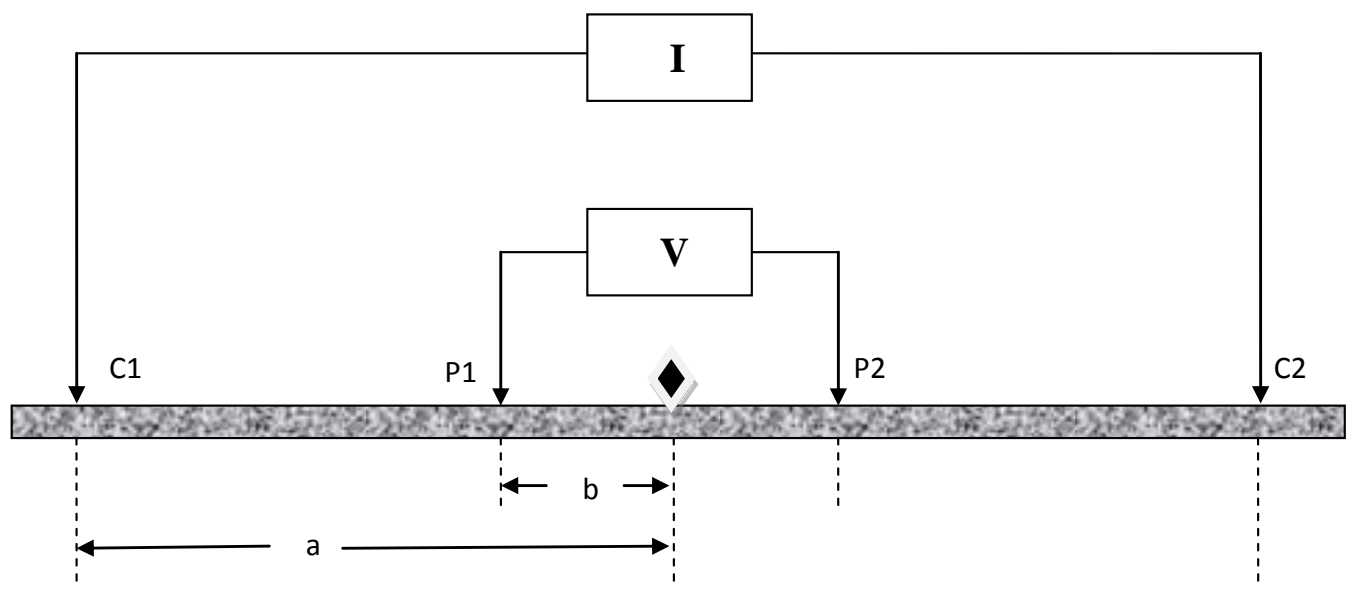

Gambar 2. Skema Konfigurasi Schlumberger 


\section{Geologi Regional Sragen}

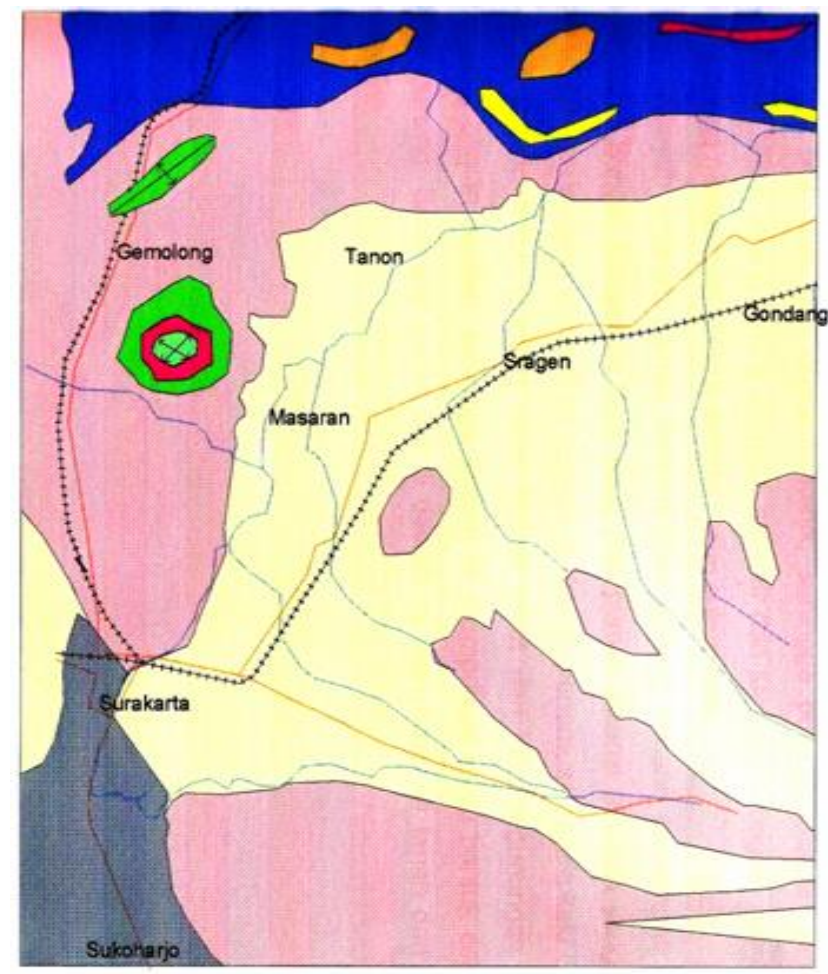

PETA GEOLOGI REGIOHAL KABUPATEN

SRAGEN DAN SEKITARHYA

Skala 1 : 25000

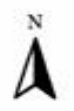

Keterangan

Sungai

- Jalan

..... Rel kereta api

f Lipatan

Alluvium

Endapan Gunungapi muda G. Lam

Formasi Notopuro

Formasi Pucangan

Formasi Kabuh

Formasi Kalibeng

Formasi Banyak

Gambar 3. (Coulor online) Peta Geologi Sragen ${ }^{[7]}$

Secara regional kondisi Geologi Sragen seperti Gambar 3 terdiri dari 6 formasi batuan yaitu Formasi Kalibeng, Formasi Kabuh, Formasi Notopuro , Endapan Gunung Api Muda dan endapan Aluvium.

Formasi Kalibeng penyebaran sangat luas, formasi ini tersusun oleh napal, berwana abuabu tua, serta setempat-setempat bersisipan dengan batu pasir berbutir, Pelapukan batuan berupa lempung, berwarna coklat kehitamanan.

Formasi Pucangan ditemukan di Sangiran dan Gemolong tersusun dari batu lempung berwarna hitam sering bersisipam dengan batu pasir.

Formasi Kabuh ditemukan di Sangiran, Gemolong dan Sumber Lawang, Batuan ini tersusun oleh batu pasir, berwarna abu-abu terang, berbutir sedang sampai kasar, keras, berstruktur silangsiur. Pelapukan batuan berupa lanau lempungan, berwarna coklat kemerahan.

Formasi Notopuro tersusun oleh tuf breksi, tuf dan batupasir tufaan. Penyebaran di bagian Barat dan Selatan.

Endapan Gunung Api Muda terdapat didaerah penelitian berasal dari kegiatan Gunung Lawu. Endapan Gunung Api Muda in terdiri atas lempung, lempung pasiran, pasir lempungan, pasir kerikilan dan breksi volkanik, kedudukan dengan formasi Notopura tidak selaras.

Endapan Aluvium di temukan di bagian Selatan dan Utara sepanjang Sungai Bengawan Solo, tersusun dari batuan lempung dan lempung pasiran dengan sedikit tufaan, pasir dan kerikil. Umumnya lempung dan lanau, berwarna kehitaman, bersifat lunak ${ }^{[7]}$ 


\section{METODE}

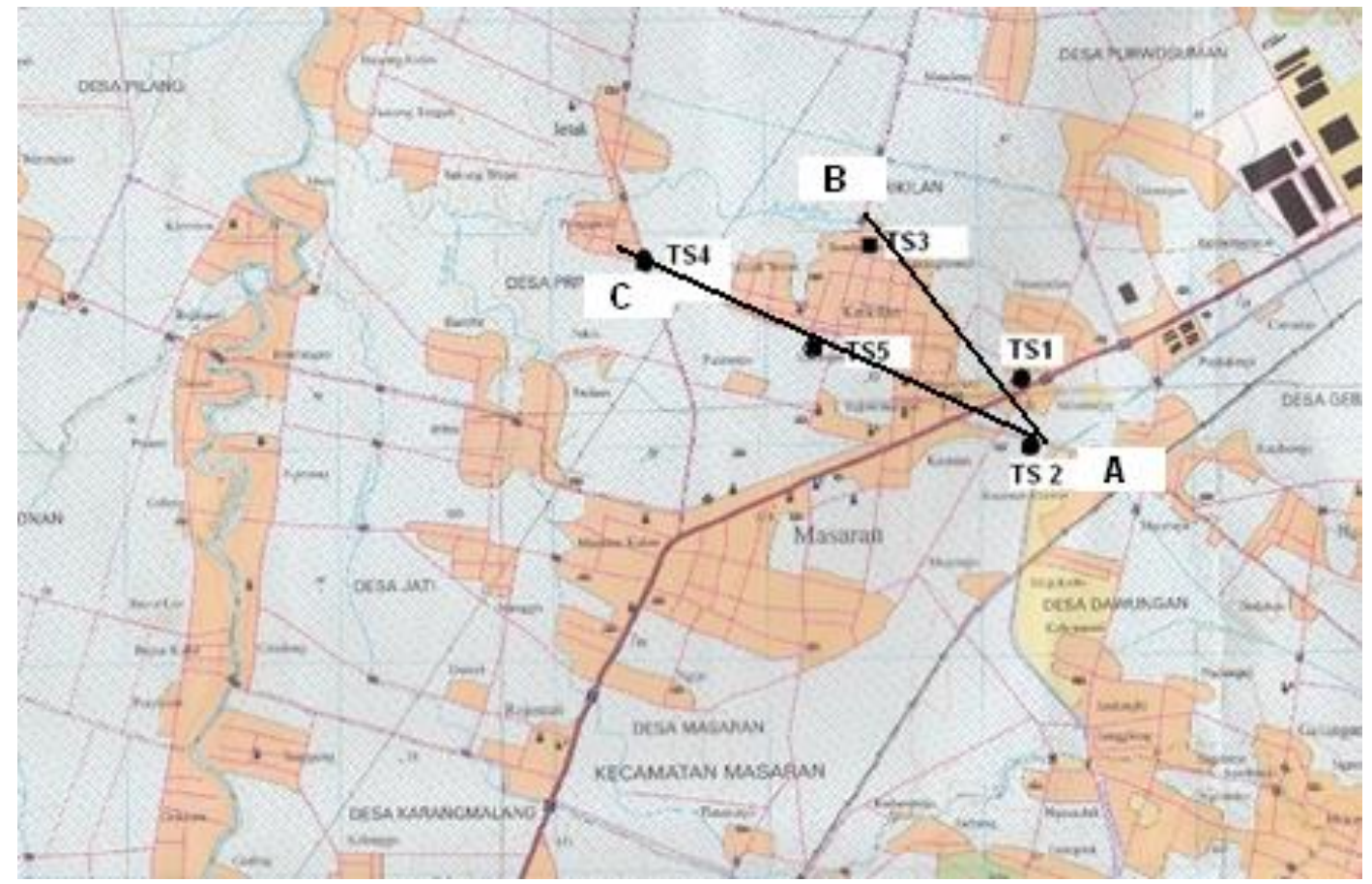

Gambar 4. (Colour online) Lokasi titik geolistrik dan garis penampang ${ }^{[8]}$

Alat yang digunakan Resistivitimeter OYO Model 2119C McOHM-EL. Pengambilan data menggunakan konfigurasi Schlumberger dengan $A B / 2$ mulai $1,5 \mathrm{~m}$ sampai $350 \mathrm{~m}$. Dengan mengetahui arus yang diinjeksikan dan tegangan yang diukur, selanjutnya di hitung niali resistivitas semunya. Pengolahan data resistivitas dilakukan dengan menggunakan software IPi2win. Hasil yang diperoleh adalah kedalaman lapisan, ketebalan lapisan dan nilai resistivitas sesungguhnya. Tahap interpretasi, mengubah hasil pengolahan data menjadi bentuk geologi, dengan melihat geologi daerah penelitian.

Pengambilan dilakukan di 5 titik geolistrik yang berada di Kecamatan Masaran yaitu TS1 (Dk. Sidomulya desa Kerikilan), TS2 (Dk. Kauman Desa Masaran) dan TS3 (Ds.Kerikilan), TS4 (Pakis desa Prianganom), dan TS5 (Desa kerikilan). Lokasi titik geolistrik seperti pada Gambar 4.

\section{HASIL DAN PEMBAHASAN}

Tabel 1. Hasil Pendugaan Geolistrik pada Titik Pengukuran TS1

\begin{tabular}{cccccc}
\hline $\begin{array}{c}\text { Lapisan } \\
\text { Ke }\end{array}$ & $\begin{array}{c}\text { Kedalaman } \\
(\mathrm{m})\end{array}$ & $\begin{array}{c}\text { Ketebalan } \\
(\mathrm{m})\end{array}$ & $\begin{array}{c}\text { Tahanan } \\
\text { Jenis } \\
(\Omega \mathrm{m})\end{array}$ & Litologi & Keterangan \\
\hline 1. & 0 & 2,15 & 9,2 & Top soil & Lapisan penutup \\
2. & 2,15 & 0,798 & 40,1 & pasir & Akuifer \\
3. & 2,95 & 1,62 & 1,8 & Lempung & Akuiklud \\
4. & 4,57 & 3,45 & 113 & Pasir kerikilan & Akuifer \\
5. & 8,02 & 3,11 & 12 & Lempung & Akuitar \\
6. & 11,1 & 3,92 & 1,12 & pasiran & Lempung \\
7. & 15,1 & 7,36 & 5,31 & lempung & Akuiklud \\
8. & 22,4 & 8,57 & 125 & Pasir kerikilan & Akuifer
\end{tabular}




$\begin{array}{cccccc}9 . & 31 & 3,8 & 37,1 & \text { Pasir } & \text { Akuifer } \\ 10 . & 34,8 & 24,8 & 0,223 & \text { Lempung } & \text { Akuiklud } \\ 11 . & 59,6 & 8,44 & 3,55 & \text { Lempung } & \text { Akuiklud } \\ 12 . & 68,1 & 9,89 & 92,3 & \text { Pasir kerikilan } & \text { Akuifer } \\ 13 . & 78 & 16,3 & 5,64 & \text { Lempung } & \text { Akuiklud } \\ 14 . & 94,3 & 20,5 & 51,3 & \text { Pasir } & \text { Akuifer } \\ 15 & 115 & 69,3 & 4,56 & \text { Lempung } & \text { Akuiklud } \\ 16 . & >184 & & 90,6 & \text { Pasir kerikilan } & \text { Akuifer }\end{array}$

Tabel 2. Hasil Pendugaan Geolistrik pada Titik Pengukuran TS2 (Ds. Kauman)

\begin{tabular}{cccccc}
\hline $\begin{array}{c}\text { Lapisan } \\
\text { Ke }\end{array}$ & $\begin{array}{c}\text { Kedalaman } \\
(\mathrm{m})\end{array}$ & $\begin{array}{c}\text { Ketebalan } \\
(\mathrm{m})\end{array}$ & $\begin{array}{c}\text { Tahanan } \\
\text { Jenis } \\
(\Omega \mathrm{m})\end{array}$ & Litologi & Keterangan \\
\hline 1. & 0 & 0,819 & 23,5 & Top soil & Lapisan penutup \\
2. & 0,819 & 2,64 & 12,1 & Lempung pasiran & Akuitar \\
3. & 3,46 & 3,86 & 3,72 & Lempung & Akuiklud \\
4. & 7,31 & 1,52 & 1,02 & Lempung & Akuiklud \\
5. & 8,84 & 2,85 & 54,3 & Pasir & Akuifer \\
6. & 11,7 & 9,26 & 99,7 & Pasir kerikilan & Akuifer \\
7. & 20,9 & 7,55 & 0,219 & Lempung & Akuiklud \\
8. & 28,5 & 8,42 & 1,1 & Lempung & Akuiklud \\
9. & 36,9 & 11,1 & 30,8 & Pasir & Akuifer \\
10. & 48 & 16,2 & 53,2 & Pasir & Akuifer \\
11. & 64,2 & 11,9 & 81,5 & Pasir kerikilan & kuifer \\
12. & 76,1 & 17,3 & 34,7 & Pasir & Akuifer \\
13. & 93,4 & 10,1 & 2,53 & Lempung & Akuiklud \\
14. & 103 & 30,2 & 33 & Pasir & Akuifer \\
15 & $>134$ & & 45,6 & Pasir & Akuifer \\
\hline
\end{tabular}

Tabel 3. Hasil Pendugaan Geolistrik pada Titik Pengukuran TS3 (Desa Krikilan)

\begin{tabular}{cccccc}
\hline $\begin{array}{c}\text { Lapisan } \\
\text { ke }\end{array}$ & $\begin{array}{c}\text { Kedalaman } \\
(\mathrm{m})\end{array}$ & $\begin{array}{c}\text { Ketebalan } \\
(\mathrm{m})\end{array}$ & $\begin{array}{c}\text { Tahanan } \\
\text { Jenis }(\Omega \mathrm{m})\end{array}$ & Litologi & Keterangan \\
\hline 1. & 0 & 0,5 & 20,8 & Top soil & Lapisan penutup \\
2. & 0,5 & 0,15 & 2,89 & Lempung & akuiklud \\
3. & 0,65 & 0,175 & 575 & Pasir kerakalan & Akuifer \\
4. & 0,826 & 0,385 & 32,6 & Pasir & Akuifer \\
5. & 1,21 & 1,66 & 2,69 & Lempung & Akuiklud \\
6. & 2,87 & 0,587 & 25,8 & Pasir lempungan & Akuifer \\
7. & 3,46 & 6,57 & 93,9 & Pasir kerikilan & Akuifer \\
8. & 10 & 3,31 & 1,22 & Lempung & Akuiklud \\
9. & 13,3 & 11 & 25,2 & Pasir lempungan & Akuifer \\
10 & 24,3 & 17,2 & 76,8 & Pasir kerikilan & Akuifer \\
11. & 41,5 & 4,42 & 13,5 & Lempung pasiran & Akuitar \\
12. & 45,9 & 26,9 & 1,04 & lempung & Akuiklud \\
13. & 72,8 & 13,7 & 146 & Pasir kerikilan & Akuifer \\
14. & 86,5 & 14,7 & 43,6 & pasir & Akuifer \\
15. & 101 & 14,5 & 5,71 & lempung & Akuiklud \\
16. & 116 & & 33,7 & Pasir & Akuifer \\
\hline
\end{tabular}

Tabel 4. Hasil Pendugaan Geolistrik pada Titik Pengukuran TS4 (Ds. Pakis Desa Pringanom)

\begin{tabular}{cccccc}
\hline $\begin{array}{c}\text { Lapisan } \\
\text { ke }\end{array}$ & $\begin{array}{c}\text { Kedalaman } \\
(\mathrm{m})\end{array}$ & $\begin{array}{c}\text { Ketebalan } \\
(\mathrm{m})\end{array}$ & $\begin{array}{c}\text { Tahanan } \\
\text { Jenis } \\
(\Omega \mathrm{m})\end{array}$ & Litologi & Keterangan \\
\hline 1. & 0 & 0,503 & 36,4 & Top soil & Lapisan penutup \\
2. & 0,503 & 0,301 & 5,12 & Lempung & Akuiklud \\
\hline
\end{tabular}




\begin{tabular}{|c|c|c|c|c|c|}
\hline 3. & 0,804 & 1,09 & 221 & Pasir kerakalan & Akuifer \\
\hline 4. & 1,89 & 0,796 & 0,467 & Lempung & Akuiklud \\
\hline 5. & 2,69 & 4,02 & 32,4 & Pasir & Akuifer \\
\hline 6. & 6,71 & 1,14 & 9,16 & Lempung pasiran & Akuitar \\
\hline 7. & 7,85 & 9,44 & 3,86 & Lempung & Akuiklud \\
\hline 8. & 17,3 & 19,1 & 90,5 & Pasir kerikilan & Akuifer \\
\hline 9. & 36,4 & 9,86 & 0,411 & Lempung & Akuiklud \\
\hline 10. & 46,3 & 21,2 & 67 & Pasir kerikilan & Akuifer \\
\hline 11. & 67,5 & 14,7 & 10,1 & Lempung pasiran & Akuitar \\
\hline 12. & 82,1 & 15,8 & 120 & Pasir kerikilan & Akuifer \\
\hline 13. & 98 & 23,8 & 5,06 & Lempung & Akuiklud \\
\hline 14. & 122 & & 25,5 & Pasir lempungan & Akuifer \\
\hline $\begin{array}{c}\text { Lapisan } \\
\text { ke }\end{array}$ & $\begin{array}{l}\text { Kedalaman } \\
\text { (m) }\end{array}$ & $\begin{array}{l}\text { Ketebalan } \\
(\mathrm{m})\end{array}$ & $\begin{array}{c}\text { Tahanan } \\
\text { Jenis } \\
(\Omega \mathrm{m})\end{array}$ & Litologi & Keterangan \\
\hline 1. & 0 & 0,526 & 25,4 & Top soil & Lapisan penutup \\
\hline 2. & 0,526 & 2,28 & 20,6 & Pasir lempungan & Akuifer \\
\hline 3. & 2,81 & 4,49 & 4,95 & Lempung & Akuiklud \\
\hline 4. & 6,3 & 9,28 & 9,85 & Lempung pasiran & Akuitar \\
\hline 5. & 15,6 & 9,44 & 29,2 & pasir & Akuifer \\
\hline 6. & 25 & 3,76 & 29,4 & Pasir & Akuifer \\
\hline 7. & 28,8 & 8,31 & 6,74 & Lempung & Akuiklud \\
\hline 8. & 37,1 & 13 & 2,88 & Lempung & akuiklud \\
\hline 9. & 50,1 & 15,5 & 69,1 & Pasir kerikilan & Akuifer \\
\hline 10. & 65,6 & 20,8 & 15,5 & Pasir lempungan & Akuifer \\
\hline 11 & 86,4 & 7,16 & 39,4 & Pasir & Akuifer \\
\hline 12 & 93,5 & 6,14 & 4,94 & Lempung & akuiklud \\
\hline 13 & 99,7 & 11,6 & 22,5 & Pasir lempungan & Akuifer \\
\hline 14 & 111 & & 0,77 & Lempung & Akuiklud \\
\hline
\end{tabular}

Hasil pengolahan data geolistrik, selanjutnya dilakukan interpretasi dengan mempertimbangkan kondisi daerah penelitian, dimana daerah penelitian termasuk dalam zona Endapan Lawu yang tersusun dari batuan pasir gunungapi, batuan lempung dan breksi. Hasil yang diperoleh seperti dalam Tabel 1 sampai Tabel 5, yang menunjukkan bahwa litologi batuan yang terdeteksi, kedalaman dan ketebalan lapisan serta nilai hambatan jenisnya, kemudian keterangan batuan yang termasuk akuifer atau bukan akuifer. Batuan yang termasuk akuifer yaitu pasir lempungan, pasir, pasir kerikilan, pasir kerakalan dan breksi. Batuan yang bukan akuifer lempung dan lempung pasiran.

Dari gambaran penampang untuk lintasan penampang sesuai Gambar 4, bahwa Penampang A-B berarah Tenggara- Barat Laut dan arah penampang A-C dari Tenggara ke Barat. Pola aliran dapat diduga dari arah TS2 yang mempunyai elevasi yang paling tinggi menuju ke elevasi yang lebih rendah. Pada Gambar 5 dan Gambar 6 menunjukkan penampang A-B dari TS2 ke TS1 terus TS3, sedangkan untuk arah penampang A-C dari TS2 ke TS5 terus ke TS4. Struktur perlapisan pada penampang A-B dan penampang A-C terdiri dari : (1) adalah lapisan lempung, (2) adalah lapisan akuifer dangkal dan (3) adalah lapisan akuifer dalam. Untuk keberadaan akuifer seperti yang ditunjukkan Gambar 5 dan Gambar 6, lapisan akuifer dangkal pada penampang A-B terdiri dari litologi pasir lempung, pasir dan pasir kerikilan, sedangkan pada penampang A-C, litologi lapisan akuifernya adalah lapisan pasir dan pasir kerikilan. Lapisan akuifer dalam pada penampang A-B terdiri dari lapisan pasir dan pasir kerikilan, sedangkan pada penampang A-C terdiri dari lapisan pasir lempungan, pasir dan pasir kerikilan. 


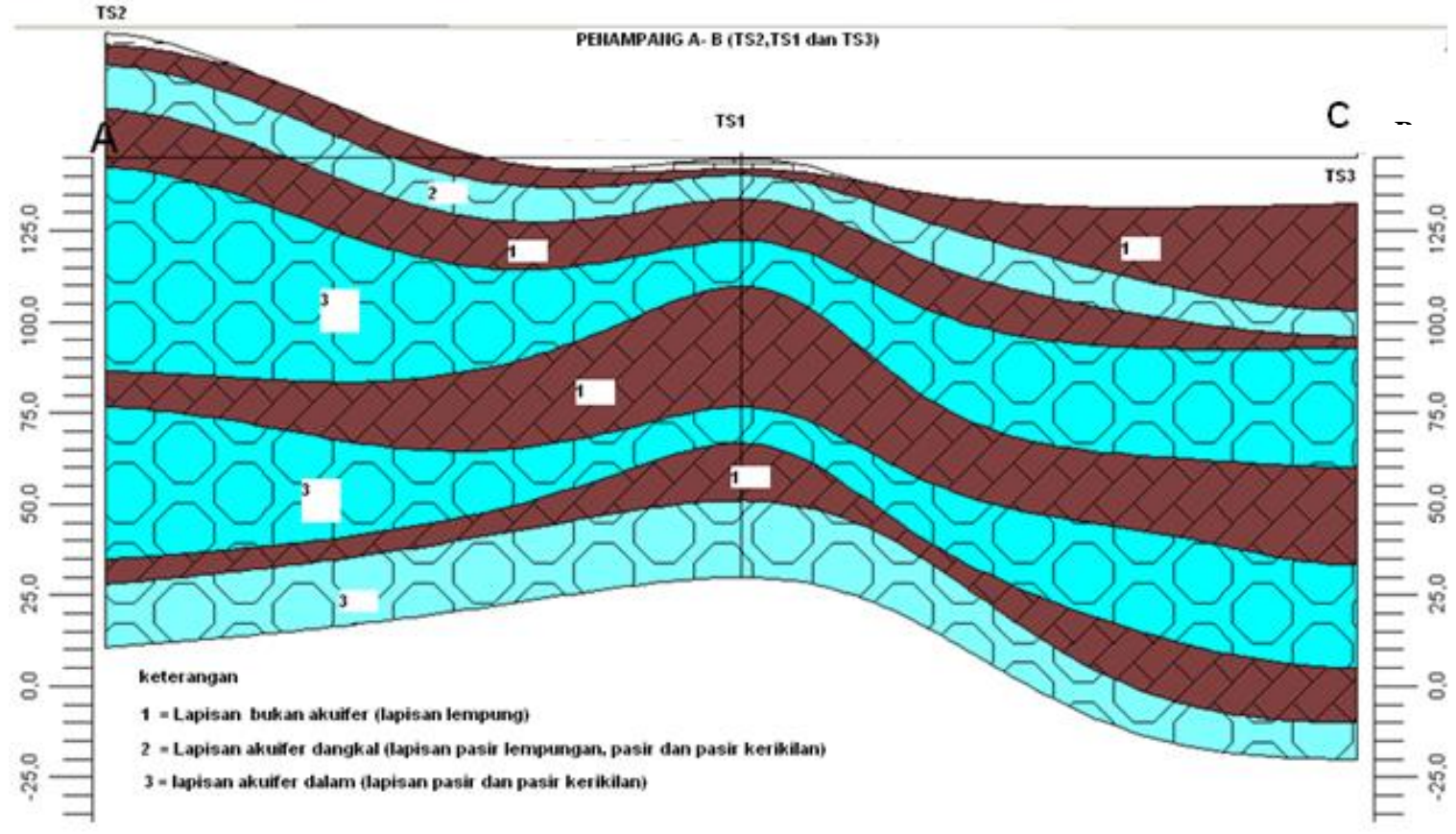

Gambar 5. (Colour online) Sruktur perlapisan penampang A-B

TS2

PENAMPANG A-C (TS2,TS5 dan TS4)

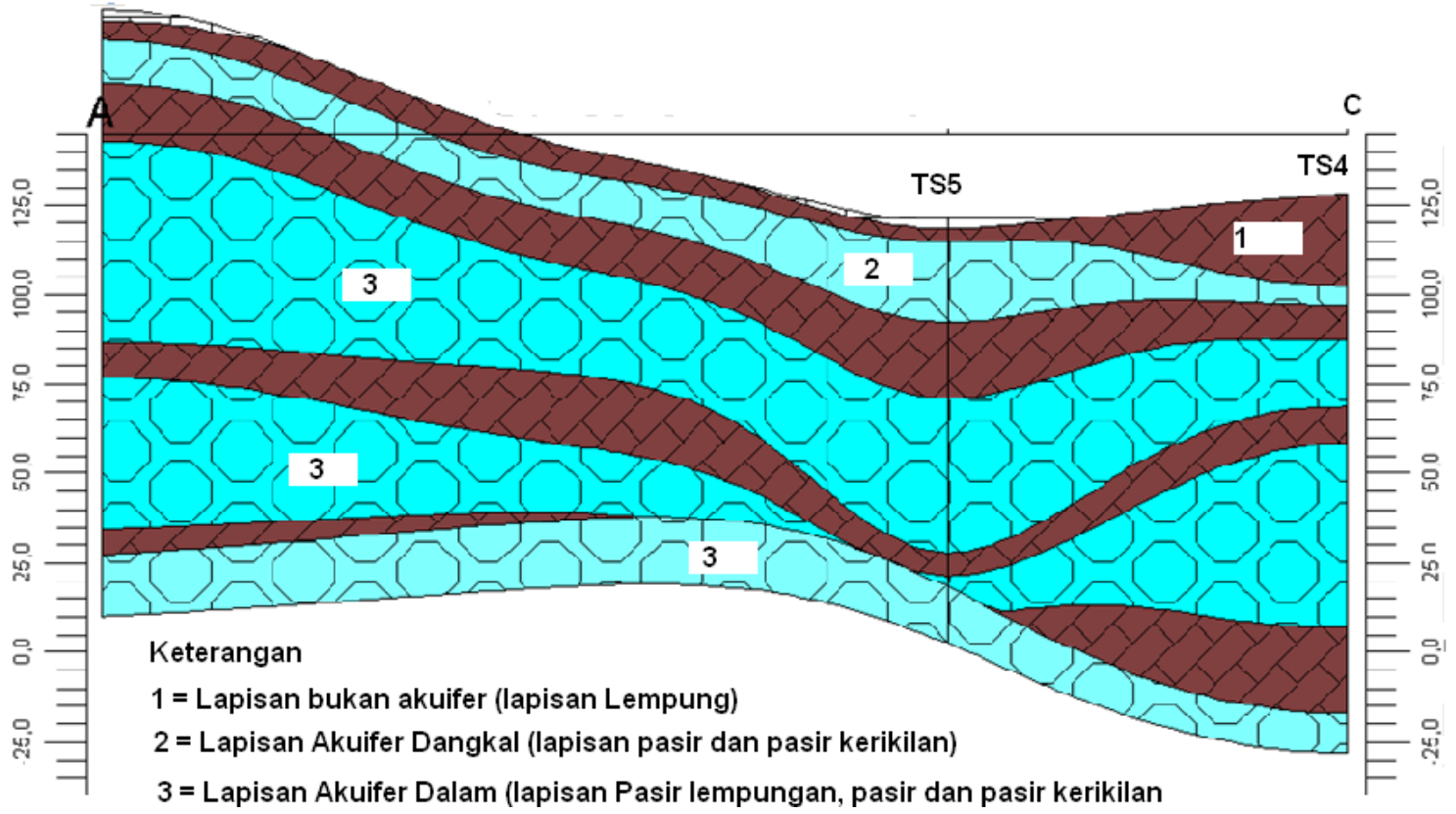

Gambar 6. (Colour online) Sruktur perlapisan penampang A-C

Untuk pola ketebalan lapisan akuifer dangkal pada penampang A-B dari TS2 menuju ke TS1 dan TS3 ketebalan makin menipis/berkurang. Sedangkan lapisan akuifer dalam dari TS2 ke TS1 mengecil kemudian ke TS3 menebal lagi. Untuk pola ketebalan lapisan akuifer dangkal pada arah penampang A-C menunjukkan bahwa dari TS2 ke TS5 terus TS4 makin mengecil ketebalannya. Sedangkan untuk pola ketebalan lapisan akuifer dalam pada penampang A-C menunjukkan bahwa lapisan akuifer dalam ada 2 lapisan, untuk lapisan akuifer dalam pertama dari TS2 ke arah TS5 terus ke TS4 makin mengecil ketebalannya. Sedangkan untuk pola ketebalan lapisan akuifer dalam kedua dari TS2 ke TS5 mengecil kemudian kearah TS4 ketebalan lapisan membesar lagi. Pola ketebalan 
lapisan akuifer dangkal dari Tenggara ke Barat Laut atau dari Tenggara ke Barat, ketebalan lapisan makin mengecil. Sedangkan pola ketebalan lapisan akuifer dalam dari arah Tenggara ke Barat laut menunjukkan pola yang berubah yaitu dari tebal mengecil ketebalannya kemudian menebal lagi. Sedangkan pola ketebalan dari arah Tenggara ke Barat terdapat dua pola yaitu pertama, makin ke arah Barat makin menipis dan pola kedua tebal menipis kemudian menebal lagi.

Identifikasi keberadaan lapisan akuifer dangkal dan lapisan akuifer dalam seperti pada Tabel 6. Lapisan akuifer dangkal terdeteksi pada kedalaman untuk TS1 (4,52 $\mathrm{m}-8,57 \mathrm{~m}$ dan 22,4 m- $34 \mathrm{~m}), \mathrm{TS} 2$ ( 8,84 m -20,9 m), TS3 (2,87 m - $10 \mathrm{~m}$ dan 13,3 m-41,5 m), TS4 (2,09 $\mathrm{m}-6,71 \mathrm{~m}$ dan17,3 $\mathrm{m}-36,4 \mathrm{~m})$ dan TS5 $(6,3 \mathrm{~m}-25 \mathrm{~m})$. Lapisan akuifer dangkal yang terdeteksi dengan kedalaman yang paling dangkal yaitu pada titik geolistrik TS3 dan TS4 yaitu terdeteksi dengan kedalaman 2,67 m dan 2,09 m, Ketebalan lapisan akuifer dangkal untuk TS1 (15,82 m), TS2 (12,11 m), TS3 (35,3 m), TS4 (23,1 m) dan TS5 $(22,48 \mathrm{~m})$ dimana ketebalan lapisan pada TS3 lebih tebal dibanding TS4.

Lapisan akuifer dalam terdeteksi pada kedalaman untuk TS1 (68,1-78 m dan 94,3-115 m), TS2 (36,9 -93,4 m dan 103-134 m ), TS3 (72,8-101 m), TS4 (46,3-67,5 m dan 82,1-98 m), dan TS5 (50,1-93,5 m dan 99,7-111 m). Ketebalan lapisan akuifer dalam terdeteksi untuk TS1 (30,6 m), TS2 (86,7 m), TS3 (28,4 m), TS4 (37 m), dan TS5 (55 m). Sumber air yang potensial dari kelima titik geolistrik berdasarkan ketebalan lapisan yang terdeteksi dan litologi lapisan menunjukkan bahwa titik geolistrik TS2 lebih mempunyai kandungan sumber air yang lebih baik dibanding titik geolistrik yang lain. Atau secara urutan prioritas TS2, TS4/TS5, TS1 dan TS3.

Tabel 6. Kedalaman dan litologi akuifer dangkal dan akuifer dalam

\begin{tabular}{|c|c|c|c|c|c|}
\hline Titik. & AKUIFER & $\begin{array}{c}\text { Kedalaman } \\
(\mathrm{m})\end{array}$ & $\begin{array}{c}\text { Tahanan } \\
\text { Jenis }(\Omega \mathrm{m})\end{array}$ & $\begin{array}{l}\text { Ketebalan } \\
(\mathrm{m})\end{array}$ & Litologi \\
\hline \multirow[t]{4}{*}{ TS1 } & Akuifer Dangkal & $4,52-8,57$ & 113 & 3,45 & Pasir, pasir kerikilan \\
\hline & & $22,4-4$ & $37,1-125$ & 12,37 & Pasir, pasir kerikilan \\
\hline & Akuifer Dalam & $68,1-78$ & 51,3 & 9,9 & Pasir \\
\hline & & $94,3-115$ & 37,1 & 20,7 & pasir \\
\hline \multirow[t]{3}{*}{ TS2 } & Akuifer dangkal & $8,84-20,9$ & $54,3-99,7$ & 12,11 & Pasir kerikilan \\
\hline & Akuifer dalam & $36,9-93,4$ & $30,8-81,5$ & 56,5 & Pasir, pasir kerikilan \\
\hline & & 103-134 & $33-45,6$ & 30,2 & pasir \\
\hline \multirow[t]{3}{*}{ TS3 } & Akuifer dangkal & $2,87-10$ & $25,8-93,9$ & 7,157 & $\begin{array}{l}\text { Pasir lempungan, pasir } \\
\text { kerikilan }\end{array}$ \\
\hline & & $13,3-41,5$ & $25,2-76,8$ & 28,2 & $\begin{array}{l}\text { Pasir lempungan, pasir } \\
\text { kerikilan }\end{array}$ \\
\hline & Akuifer dalam & $72,8-101$ & 43,146 & 28,4 & $\begin{array}{l}\text { pasir lempungan Pasir } \\
\text { kerikilan }\end{array}$ \\
\hline \multirow[t]{4}{*}{ TS4 } & Akuifer Dangkal & $2,09-6,71$ & 32,4 & 4,02 & Pasir \\
\hline & & $17,3-36,4$ & 90,5 & 19,1 & Pasir kerikilan \\
\hline & Akuifer Dalam & $46,3-67,5$ & 67 & 21,2 & Pasir kerikilan \\
\hline & & $82,1-98$ & 120 & 15,8 & Pasir kerikilan \\
\hline \multirow[t]{2}{*}{ TS5 } & Akuifer dangkal & $6,3-25$ & $9,05-29,4$ & 22,48 & $\begin{array}{l}\text { Lempungan pasir dan } \\
\text { pasir }\end{array}$ \\
\hline & Akuifer dalam & $50,1-93,5$ & $15,5-69,1$ & 43,46 & Pasir lempungan, pasir \\
\hline
\end{tabular}

\section{KESIMPULAN}

Identifikasi keberadaan lapisan akuifer dangkal dan lapisan akuifer dalam, menunjukkan bahwa Lapisan akuifer dangkal terdeteksi pada kedalaman untuk TS1 (4,52 m-8,57 m dan 
22,4 m-34 m), TS2 ( 8,84 m-20,9 m), TS3 (2,87 m-10 m dan 13,3 m-41,5 m), TS4 (2,09 m-6,71 m dan17,3 m-36,4 m) dan TS5 (6,3 m-25 m). Ketebalan lapisan akuifer dangkal untuk TS1 (15,82 m), TS2 (12,11 m), TS3 (35,3 m), TS4 $(23,1 \mathrm{~m})$ dan TS5 $(22,48 \mathrm{~m})$, Lapisan akuifer dangkal yang mempunyai lapisan paling tebal adalah pada TS3. Lapisan akuifer dalam terdeteksi pada kedalaman untuk TS1 (68,1 m-78 m dan 94,3 m-115 m), TS2 (36,9 -93,4 m dan 103-134 m ), TS3 (72,8 -101 m), TS4 (46,3-67,5 m dan 82,1 -98 $\mathrm{m})$, dan TS5 (50,1-93,5 m dan 99,7-111 m). Ketebalan lapisan akuifer dalam terdeteksi untuk TS1 (30,6 m), TS2 (86,7 m), TS3 (28,4 m), TS4 (37 m), dan TS5 (55 m). Lapisan Akuifer Dalam yang mempunyai lapisan yang paling tebal adalah TS2.

\section{DAFTAR PUSTAKA}

1. Todd, D. K. 1980. Ground-water hydrology (Second Edition). John Wiley and Sons: New York, pp. 535.

2. Bouwer, H. 1978. Groundwater hydrology. McGraw-Hill, New York, NY, pp. 480

3. Kruseman, G.P., and deRidder, N.A. 1990. Analysis and evaluation of pumping test data (Second edition). International Institute for Land Reclamation and Improvement, Wageningen, the Netherlands, $377 \mathrm{p}$.

4. Gash, B. 2007. Groundwater Aquifers. The Richard Stockton College of New Jersey: Pomona, New Jersey.

5. Lilik Hendrajaya dan Idam Arif. 1990. Geolistrik Tahanan Jenis. Laboratorium Fisika Bumi Jurusan Fisika FMIPA. ITB.

6. Telford, W. M., Geldart, L. P., Sheriff, R.E., and Keys, D. A. 1998. Applied Geophysics. Cambridge University Press.

7. Suharyadi. 2004. Laporan Akhir Penelitian Geolistrik Di Kecamatan Gemolong Kab. Sragen. Laboratorium Geologi Tata Lingkungan Jurusan Teknik Geologi Fakultas Teknik Universitas Gadjah Mada. Yogyakarta

8. Bakorsurtanal. 2000. Peta Rupabumi Digital Indonesia, Skala 1: 25.000. Lembar Masaran. Cibinong. 